\title{
IAMJ
}

INTERNATIONAL

AYURVEDIC

MEDICAL JOURNAL

\section{A REVIEW ON THE THERAPEUTIC EFFECTS OF NETI KRIYA}

\author{
Priyanka V', Yogesh Jakhar², Anupam pathak ${ }^{3}$ \\ ${ }^{1}$ PG Scholar, ${ }^{2}$ Assistant Professor, ${ }^{3}$ Professor \\ Dept of Swasthvritta, Sriganganagar College of Ayurvedic Sciences \& Hospital, Tantia University, Sriganganagar \\ - 335001, India
}

Email: doc.vashist22@gmail.com

\section{https://doi.org/10.46607/iamj0807232020}

(Published online: July 2020)

Open Access

(C) International Ayurvedic Medical Journal, India 2020

Article Received: 08/06/2020 - Peer Reviewed: 21/06/2020 - Accepted for Publication: 01/07/2020

\section{Check for updates}

\begin{abstract}
Yoga as an ancient science can help people live a long and healthy life. This science has now become increasingly popular in many countries. There are several health conditions that can be cured or at least alleviated to a great extent, through the practice of this science. Yoga includes Asana, Pranayam and exercises that can help body, immunity, increase strength, weight loss, remove stress and relief from pains, infections and disorders. Some of the various yoga poses and techniques can be used to cure numerous conditions ranging from nasal polyps to cancer. Since a sinus infection is one of the most common respiratory ailments that people suffer from, it is only common for them to use natural practices to cure this condition. Yoga practice, which is known as Jala neti or Sutra neti, i.e., cleansing of nasal cavity, throat can help reduce the pain and discomfort due to sinusitis, within a shorter period of time. These procedures are known as Neti kriya. Neti kriya is an integral part of shatkarmas / the six cleansing techniques that form the most important aspect of hatha yoga. Neti helps in preventing and managing upper respiratory tract diseases. An attempt is being made to collect and review articles that highlight the therapeutic effects of neti kriya. Databases like Pub Med (January 1980-April 2016), Scopus and Ayush Portal were searched. We used keywords like jala neti, neti kriya, neti combined with terms such as yoga, sinusitis, rhinitis, common cold, vision, snoring, nasopharyngeal carcinoma and mental health for the search. As only a few results were obtained, we reviewed relevant studies with saline nasal irrigation. Evidence emerging from this review suggests that neti offers manifold benefits and relief from the antibiotic grip. Most studies support the role of neti in treating sinusitis, rhino
\end{abstract}


sinusitis, and allergic conditions and in improving vision. Jala neti has a significant role in improving the presence of mind and intelligence.

Keywords: Yoga, Jala Neti, Sutra Neti.

\section{INTRODUCTION}

Hatha Yoga has given great importance to shat karmas (6 processes) or shuddhi kriyas for the body and mind purification. Without purification of the body one will not be ready for the practice of yoga. Shat karmas cleanse and activate all vital organs of the body especially the digestive, respiratory, circulatory and nervous systems. They are preventive as well as curative in nature. The six main yogic Shat kriyas are as follows: * Neti, Dhouti, Nauli, Basti, Tratak, Kapalbhati. Hatha Yoga Pradipika (H.P) ${ }^{1}$ and Gheranda Samhita ${ }^{2}$ described Shatkarmas. 'Shat' means six and 'karma' implies action; Shatkarma consists of the six purificatory procedures. It should be practiced when Medas and Kapha were in excess. Dhauti, Basti, Neti, Trataka, Nauli and Kapalabhati were the six cleansing processes ${ }^{3}$. Among these Neti eradicates Kaphaja disorders and improves vision $^{4}$. Improper management of sinusitis and associated symptoms lead to asthma. In India, there are an estimated 15-20 million asthmatics ${ }^{5}$. WHO estimates that 235 million people currently suffer from asthma ${ }^{6}$. There is not much proof to substantiate the benefits of using antibiotics routinely in the treatment of upper respiratory tract infections in children or adults. Also, there is an increase in adverse effects associated with the usage of antibiotics in adult patients ${ }^{7}$. Hence there is a need for a non-pharmacological, lowcost, effective mode of treatment to improve the quality of health. The objective of the review was to summarize current pieces of evidence from authentic studies on the therapeutic effects of Neti Kriya.

\section{Neti}

$N e t i$ is a technique to cleanse the nasal passages. It is a cleansing process related to the upper part of the respiratory system. Neti may be broadly classified into jala neti and sutra neti. Although authentic references are not available for jala neti, it is most widely practiced. It is usually practiced with a neti pot filled with lukewarm saline water. The exact amount of salt is not mentioned in any traditional texts. Practically it is about $2.5 \mathrm{~g}$ for $500 \mathrm{~L}$ of water. Based on clinical studies use of proper salt concentration (2-3.5\%) has been recommended in nasal irrigation ${ }^{8}$. It is ideally practiced in morning before asanas and pranayama.

\section{Sutraneti}

The classical form of neti described is Sutra neti where a soft lubricated thread is inserted through nose to the length of one hand span so that it comes out of mouth. Sutra Neti is performed with a rolled string of cotton which has previously been dipped in melted bees wax, or a soft rubber catheter. The width of thread should be $4 \mathrm{~mm}$ and length $36 \mathrm{~cm}$.

\section{Technique}

1. Sit in kagasana. Insert the sutra neti into one of the nostrils, whichever is more activate the movement, using both the hands to push it through.

2. When cord comes to throat catch hold of the cord with index and middle finger and draw it out slowly through the mouth.

3. The cord is gently pulled to and fro for some time, removed and then threaded through the other nostril and out the mouth again with practice the cord can be passed in one nostril and out the other nostril.

4. This technique needs some practice and, therefore, for the first time it should only be practiced under the guidance of a Yoga teacher.

\section{Benefits}

- Sutra neti stimulates the nerves and related brain functions of the eyes, tear ducts and olfactory zone.

- It increases mucus briefly, flushing out the secretory glands and removing stagnation of the blood.

- Increases resistance to invasion of viruses

- Clears away the dried-up mucus deposits and foreign particles and should be followed by jala neti. 
- This practice assists in balancing the airflow of the two nostrils

\section{Jalaneti}

Sutra neti is associated with practical inconvenience of putting the thread inside the nose which requires expertise and especially prepared thread. Thus, these facts have limited the practice of Sutraneti and to overcome these contemporary yoga experts promoted Jalaneti. In Jalaneti sutra is replaced by smooth flow of water stream into the nasal passage that comes out thorough nostril instead of mouth. Jalaneti can be done at any time of the day. It requires specially made vessel, the Neti Pot, with warm, salty water. The temperature of the water should be $38-40^{\circ} \mathrm{C}$, with about 1 teaspoon of salt per 1 litre of water.

\section{Technique}

1. Sit in kagasana or bend the head over a wash basin and gently insert the spout of the Neti Pot into the right nostril (which as a result, closes it).

2. Bend the head slightly forward and at the same time tilt the head to the left so that the water may flow out of the left nostril. Breathing takes place through the opened mouth. Keep the body relaxed.

3. Pour approximately half the contents of the pot through the right nostril and clear the nostril.

4. Now gently insert the spout of the Neti Pot into the left nostril and tilt the head to the right, so that the water may flow out through the right nostril. When finished, blow out all remaining water from both nostrils using the technique of Kapala Bhati Pranayama.

\section{Precautio}

To complete the purification of the nose, strongly expel the breath a further 3-5 times through

Each nostril while holding the other nostril shut (as when blowing your nose). It is important

That the mouth remains open during this process to prevent water getting into the ears.

\section{Benefits}

- Neti removes all the dirt and bacteria filled mucus from the nasal cavity

- Helps to drain sinus cavity which helps to reprogramme the body's natural mechanism against nasal infections
- Thinning remaining mucus so that sinuses and Ostia don't clog 9,10

- Decreasing swelling of the nasal mucosa ${ }^{9,11}$

- Removing histamine, leukotrienes, and other inflammatory substances 9,12

- Increasing frequency that cilia beat to remove mucus, crusts and debris

- It has cooling and soothing effect on the brain by drawing out excessive heat and therefore beneficial for headaches and mental tension

- Has a positive influence on all sense organs in the head. Strengthens vision and relieves tired eyes (e.g. after working long hours at the computer).

- Neti can also cure or at least ease hay fever and pollen allergies.

\section{DISCUSSION AND CONCLUSION}

According to yogic literature, neti is an important shatkriya which play a great role in managing upper respiratory tract diseases. This review was done to bring to light the therapeutic efficacy of neti kriya. We found that only minimal studies were published in indexed journals like Pub Med, Scopus and Ayush Portal. Limited available yogic literary works and lack of research were the main shortcomings. Apart from neti, we looked into related studies with saline nasal irrigation. Studies signal that progression and occurrence of upper respiratory tract infections can be greatly reduced by the practice of jala neti. Researches support its efficacy in managing sinusitis, allergic conditions and improving vision. It appears to be equally effective in children and adults. The promising result of jala neti in improving the intellectual potential of mentally retarded needs to be explored. The simple cost-effective, non-pharmacological mode of treatment can reduce the use of antibiotics and other suppressants. Further studies are needed to prove the efficacy of this therapy and establish the same as a science-based, evidence-based practice. 


\section{REFERENCES}

1. S. Muktibodhananda Hatha yoga pradipika (4th ed.), Yoga Publications Trust, Bihar (2014) Google Scholar

2. R. Bahadur, S. Chandra Vasu The gheranda Samhita (1st ed.), Chaukhamba Sanskrit Pratishthan, Varanasi (2003) Google Scholar

3. S. Muktibodhananda Hatha yoga pradipika. Shatkarma and pranayama: chapter 2, verse 22 (4th ed.), Yoga Publications Trust, Bihar (2014), p. 186. View Record in Scopus Google Scholar

4. R. Bahadur, S. Chandra VasuThe gheranda samhita. The training of the physical body: chapter 1 , verse 51 (1st ed.), Chaukhamba Sanskrit Pratishthan, Varanasi (2003), p. 18 View Record in Scopus Google Scholar

5. World Health Organization. Bronchial asthma n.d. Available from: http://www.who.int/mediacentre/factsheets/fs206/en/. [Accessed 10 May 2017]. Google Scholar

6. World Health Organization. Chronic respiratory diseases n.d. Available from: http://www.who.int/respiratory/asthma/en/. [Accessed 10 May 2017]. Google Scholar

7. B. Arroll, T. Kenealy Antibiotics for the common cold and acute purulent rhinitis B. Arroll (Ed.), The Cochrane database of systematic reviews, John Wiley \& Sons, Ltd., Chichester, UK (2005), p. CD000247 View Record in Scopus Google Scholar

8. N. Achilles, R. Mösges Nasal saline irrigations for the symptoms of acute and chronic rhinosinusitis Curr Allergy Asthma Rep, 13 (2013), pp. 229-235 Cross Ref View Record in Scopus Google Scholar

9. Georgitis, JW. Nasal Hyperthermia and Simple Irrigation for Perennial Rhinitis: Changes in Inflammatory Mediators. Chest, 1994; 106: 1487-1492.

10. Homer JJ et al. The effect of hypertonicity on nasal mucociliary clearance. Clin Otolaryngol, 2000; 25: 558-60.

11. Bachman $G$ et al. Effect of irrigation of the nose with isotonic salt solution in adult patients with chronic paranasal sinus disease. Eur Arch Otorhinolaryngol, 2000; 257: 537-541.

12. Ponkau et al. Striking deposition of toxic eosinophil major basic protein in mucus: implications for chronic rhinosinusitis. J. Allergy Clin Immun, 2005; 116(2): 362369.

\section{Source of Support: Nil \\ Conflict of Interest: None Declared}

How to cite this URL: Priyanka V et al: A Review On The Therapeutic Effects Of Neti Kriya. International Ayurvedic Medical Journal \{online\} 2020 \{cited July, 2020\} Available from: http://www.iamj.in/posts/images/upload/3964 3967.pdf 